\title{
Reviews
}

MAIRE LEADBEATER is spokesperson for the Indonesian Human Rights Committee and is writing a book on NZ and East Timor.

\section{A shameful tale of genocide and human suffering}

A Not-So-Distant Horror: Mass Violence in East Timor, by Joseph Nevins. Ithaca and London: Cornell University Press, 2005, 273pp., ISBN 0801443067 (cloth); 08014 89849 (pbk).

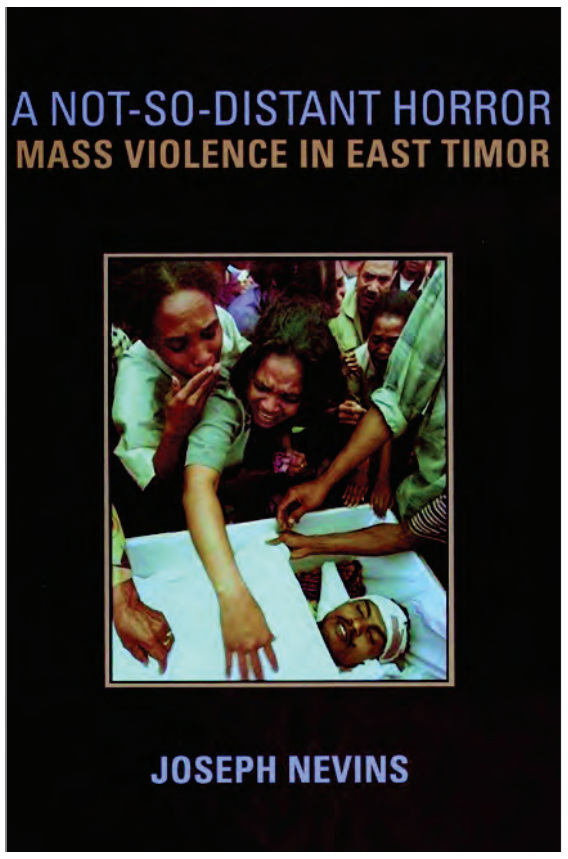

$\mathrm{W}$

ILL THE world forget the paroxysm of murderous violence that erupted when the East Timorese voted overwhelmingly for independence on 30 August 1999? In spite of the presence of the United Nations, East Timor was then reduced to 'ground zero' before the international community finally intervened. While New York's September 11 ground zero is part of daily discourse, East Timor's nightmare has been consigned to the past.

In an account described by Noam Chomsky as 'searingly honest', Joseph Nevins exposes and analyses how Western nations conspired together for more than two decades to back Indonesia and keep the East Timor issue out of the spotlight. The price paid by the East Timorese was a loss of life estimated at close to 200,000 , or a third of its population, proportionally one of the worst cases of genocide since World War II.

Nevins begins by zooming in 
close so we can meet with him some of the courageous friends he made in occupied East Timor.

His visits began in 1992, not long after the critical time when film of the Santa Cruz massacre was smuggled out and images of terrified and dying young people were beamed into television screens around the world. He describes a pervasive atmosphere of fear, an 'institutionalised' occupation replete with ever-present military and intelligence surveillance. But he also records the remarkable persistence and ingenuity of the clandestine resistance network.

Then he takes us to meet the Western architects of East Timor's tragedy. He has distilled key information from a wide range of sources including previously classified diplomatic documents from the world's powerful capitalist nations. The United States, Indonesia's 'most important international backer' (p. 44), effectively gave permission for military aggression. In a July 1975 meeting between President Suharto and US President Gerald Ford, the two leaders came to an understanding that East Timor's future lay with Indonesia. In December, Secretary of State Henry Kissinger appealed for a delay in proceedings so that he and his boss, President Ford, would have time to return to the United States follow- ing a visit to Jakarta. The full-scale invasion took place 14 hours after their departure.

Nevins also focuses on Australia's role from the time of the crucial 1974 meeting between President Suharto and Australia's Prime Minister Gough Whitlam. Whitlam's clear enthusiasm for Indonesian control of East Timor is understood to have been critical in easing Suharto's fears that the West would create a fuss about a military takeover. Throughout the occupation Australia offered 'steadfast' and, at times, 'slavish' diplomatic support for Jakarta.

While most Western nations deserve a share of blame for their acquiescence in the suffering of the East Timorese, the 'big five' were Australia, Britain, Japan, New Zealand and the United States. These nations provided the military, economic and diplomatic assistance without which the invasion could not have taken place nor could the occupation have persisted.

New Zealand was no minnow and Nevins rightly highlights the shameful role the NZ Government played throughout. New Zealand failed to reveal what it knew about Indonesia's invasion preparations, helped to propagate the fiction that the East Timorese had accepted Indonesian rule and went to extraordi- 
nary lengths to exclude roving resistance emissary Jose Ramos Horta who is now that nation's foreign minister. Nevins recounts how Indonesia was helped by negligent Western news reporting, ranging from an East Timor news blackout in the immediate postinvasion years to a predominance of 'shallow and misleading' stories. With honourable exceptions the West's role was not subjected to scrutiny and Indonesian propaganda was recycled, for example when the conflict was falsely portrayed as being about factional infighting.

Even now Indonesia successfully restricts the entry of journalists to conflict-ridden West Papua, despite its shared border with Papua New Guinea. When West Papuan human rights or self-determination issues are discussed the debate is often defined in Indonesian terms as being one about 'separatists' and the threat they pose to the territorial integrity of the unitary state.

However, perhaps the most significant message about East Timor is that the violence continues in a different form, which Nevins describes as 'silent violence'. East Timor is the poorest country in South East Asia with an appalling rate of infant mortality more than 11 times that of Australia and New Zealand. Yet Australia is exploiting vast oil reserves in the
Timor Sea and cannily refuses to allow international maritime boundary arbitration as this would be likely to endorse East Timor's claim to a larger share of this desperately needed resource. This dramatic example of socio-economic inequality is just one symptom of a world order which works in the interest of the strong and powerful.

Nevins concludes with a compelling ethical argument that remembering and accounting for the crimes against the East Timorese is a key to appreciating the reality of unjust power in our world.

The dispossessed, the occupied and colonised, are typically not allowed to use force to secure what is theirs; if they do try, their actions are often labelled terrorism. What is worse, the weak, as a way of endearing themselves to the powerful, often have to pretend that injustices for which they crave justice and accountability never happened. This too is a manifestation of violence (p. 202).

As if to underline Nevins' message, not long after the publication of this book, President Xanana Gusmao could no longer delay releasing the report of the Timor Leste Commission for Reception, Truth and Reconciliation. The commission's recommendations call for reparations to be 
paid by Indonesia as well as by those states and corporations which supported the occupation and benefited from it. But Timor Leste's leadership, anxious not to provoke Indonesia or its Western donors, has scorned the idea of compensation.

In the early days of the occupation, New Zealand officials recorded with apparent relief that there was little 'public constituency' on the East Timor issue. I believe that the growth of this constituency helped to modify New Zealand's pro-Indonesia policy and restrains the Government even now from resuming military ties with Indonesia's unreformed military.
Sadly, despite a strong and well-coordinated lobby campaign in the United States, late last year the US State Department waived all restrictions on military ties and defence exports. Perhaps Nevins could have given more weight to the activities of the international solidarity movement, but that story deserves its own book.

\title{
West Papua-the hidden Pacific conflict
}

\author{
A seminar at AUT University \\ 18-19 August 2006
}

West Papua, our Pacific neighbour, has been under Indonesian rule since 1963. At least 100,000 have died in an ongoing resistance struggle. In Australia, West Papua is on the agenda because 43 West Papuan asylum seekers became the focus of a diplomatic row between Jakarta and Canberra but the issues remain largely unknown in New Zealand.

Keynote Speaker: West Papuan Baptist Leader Socratez Sofyan Yoman

Also: Workshops, documentary film and a politicians' forum

Topics will include the historical background, human rights situation, mining and logging impacts, the role of the international community and the prospects for peace.

All welcome: For further information, please contact: Indonesia Human Rights Committee Box 68-419, Auckland. maire@clear.net.nz 